\title{
Diharapkan Dewan Perwakilan Rakyat Berperan Sebagai Inisiator Memberdayakan Pelayanan Kesehatan Primer Untuk Kesejahteraan Masyarakat
}

\section{The Parliament is expected to Serve Initiator of Empowering As Primary Health Care For Public Welfare}

\author{
Buchari Lapau
}

\section{Majelis Kolegium Kesehatan Masyarakat Indonesia}

\begin{abstract}
ABSTRAK
Di Indonesia masalah kesehatan masih tinggi, yang perlu diatasi dengan Pelayanan Kesehatan Primer (PKP) yang efektif, efesien dan bermutu. Departemen kesehatan telah menetapkan pelaksanaan MDG (millenium development goals) yang harus dicapai pada tahun 2015. Tujuan makalah ini membahas bagaimana seharusnya dapat menciptakan pelayanan kesehatan primer termasuk pencapaian MDG yang efektif, efisien dan bermutu. Untuk mencapai tujuan tersebut maka dilakukan tinjauan kepustakaan tentang upaya kesehatan, MDG, pengambilan keputusan berdasarkan bukti, pembiayaan kesehatan, desentralisasi pelayanan kesehatan, dan pendidikan tinggi kesehatan masyarakat. Di samping itu dibahas kaitan peranan DPR dengan masalah yang ditemukan. Disimpulkan bahwa pemerintah seakan-akan hanya mementingkan pencapaian MDG dari pada pelayanan kesehatan primer, pengambilan keputusan berdasarkan bukti belum berjalan, alokasi pembiayaan untuk pelayanan kesehatan primer yang bersifat preventif dan promotif jauh lebih kurang daripada pelayanan kesehatan kuratif, dalam desentralisasi pelayanan kesehatan penguasa di daerah cenderung mengangkat pejabat kesehatan yang tidak selalu berasal dari lulusan pendidikan kesehatan, dan lulusan pendidikan kesehatan masyarakat belum mampu mengelola pelayanan kesehatan yang menghasilkan informasi dan bukti untuk pengambilan keputusan. DPR belum menggunakan peranannya sebagai pembuat undang-undang dan pengawasan untuk mengatasi masalah tersebut. Disarankan supaya dibuat rencana strategis pelayanan kesehatan primer untuk mencapai tujuannya termasuk MDG bidang kesehatan untuk mengahasilkan informasi dan bukti dalam rangka menciptakan pelayanan yang efektif dan efesien dan bermutu; secara bertahap memprioritaskan pelayanan kesehatan preventif dan promotif dari pada kuratif; penguasa daerah supaya selalu mengangkat pejabat kesehatan dari lulusan pendidikan kesehatan; merencanakan dan menerapkan kurikulum yang mengarah kepada pelayanan berdasar bukti untuk pendidikan kesehatan masyarakat. DPR RI seharusnya berinisiatif sesuai dengan fungsinya supaya saran-saran tersebut diatas dapat direncanakan dan dilaksanakan oleh pemerintah.
\end{abstract}

Kata kunci : Masalah kesehatan, preventif, promotif, bukti, efektif, efisien, pembiayaan

\section{ABSTRACT}

In indonesia the health problem is still hight, which is necessary to be solved throught effective, efficient and qualified Primary Health Care (PHC). The primary of Health has confirmed the implementation of MDGs (Milenium Development Goals) which should be achieved by 2015. The objective of this paper to discuss how should be able to create services of effective, efficient and qualified PHC including MDGs. To achieve the objective there was conducted literature review on comprehensive health care, MDGs, evidence based,decision making, health financing decentralization health services and hight education of public health. Besides, then is discussed the relation parliament role duel the identified problem. The conclusion is as follows: the goverment has been likely to priority MDGs than PHC, evidence based decision has not been running, health financing allocation for preventive and promotive PHC is less than curative sevices, the local goverments too not appoint health officials from those graduated from hight education in public health have not able to produce Information and evidence for making decision. The parliament has not used the role as to formulate the low and control to solve the problem. In decentralised health services. It is sugested to formulated strategic planning for the achievment of PHC including MDGs in health to produce information and evidence for creating efective, efficient and qualified health services; To prioritise prevention and promotion more than curative health service; local an step by step; those having authority in local goverments always appoint health officials from those educated in health field; To plan and implement the curiculum directed to evidence based health service hight education in public health. The Parliament should initiate based in their function so that sugesstion mentioned above can be planed and implemented by the goverment.

Keyword: Health problem, preventive, promotive, evidence, effective, eficient, qualified.

Alamat Korespodensi : Buchari Lapau, Prodi Magister IKM STIKes Hang Tuah Pekanbaru, Jl. Mustafa Sari No. 5 Tangkerang Selatan, Pekanbaru Riau, Hp 08129210225 


\section{PENDAHULUAN}

Di Indonesia sampai saat ini angka kematian neonatal, bayi dan balita berbeda-beda diantara pedesaan dan perkotaan, kaya dan miskin, pendidikan tinggi dan pendidikan rendah, dan diantara propinsi; status gizi kurang dan buruk, dan berat badan lahir rendah (BBLR) juga berbeda diantara propinsi (Bachtiar, 2011). Penyakit-penyakit demam berdarah, malaria, ISPA, TB dan penyakit-penyakit menular lainnya belum terlihat cenderung menurun secara signifikan. Di samping itu beberapa penyakit tidak menular seperti penyakit jantung koroner, diabetes melitus, dan beberapa jenis kanker meningkat pula. Sebetulnya kematian dan penyakit-penyakit tersebut dapat dikurangi, apabila pelayanan kesehatan primer yang termasuk dalam upaya kesehatan masyarakat (UKM) berjalan dengan baik yaitu efektif, efesien dan bermutu.

Dalam Sistem Kesehatan Nasional (Depkes, 2004) tertulis dua upaya kesehatan yaitu Upaya Kesehatan Masyarakat (UKM) dan Upaya Kesehatan Perorangan (UKP). UKM merupakan pelayanan kesehatan kepada masyarakat yang jauh lebih banyak bersifat preventif yang mencegah kejadian penyakit dan masalah kesehatan lainnya; UKM juga pelayanan yang bersifat promotif, yang dapat meningkatkan kesehatan manusia sehingga manusia yang bersangkutan menjadi produktif. Jadi kalau UKM berhasil maka dapat mengurangi frekuensi penyakit dan masalah kesehatan lain sehingga dapat menghemat biaya karena tidak banyak orang yang harus diobati di rumah sakit. UKP adalah pelayanan kepada individu yang bersifat kuratif, yang banyak dilaksanakan di rumah sakit; bila UKM tidak berhasil, orang yang harus diobati dan dirawat dirumah sakit bertambah banyak sehingga terjadi pemborosan biaya dalam pelayanan kesehatan.

UKM terdiri atas tiga strata yaitu strata pertama, strata kedua dan strata ketiga. UKM strata pertama mempunyai 3 fungsi yaitu 1) Pusat penggerak pembangunan berwawasan kesehatan, yang dilaksanakan melalui lintas sektor; 2) Pusat pemberdayaan masyarakat di bidang kesehatan; dan 3) Pusat pelayanan kesehatan primer sebagai unit pelayanan kesehatan perifer di puskesmas.

Unit pelayanan kesehatan primer yang termasuk dalam UKM strata pertama dan dilaksanakan di tingkat puskesmas sekurang-kurangnya terdiri atas 1)Pelayanan promotif termasuk promosi kesehatan, kesehatan ibu dan anak dan perbaikan gizi; 2) Pelayanan preventif termasuk keluarga berencana, kesehatan lingkungan dan pengendalian penyakit; dan 3) Pelayanan kesehatan kuratif yang mencakup pengobatan sederhana.

Penanggung jawab manajemen pelayanan kesehatan primer yang termasuk kedalam UKM strata kedua adalah Dinas Kesehatan Kabupaten/Kota yang didukung secara lintas sektor, sedangkan yang termasuk strata ketiga adalah tingkat propinsi dan tingkat pusat dalam rangka pelayanan preventif, promotif yang optimal dan pelayanan kuratif yang sederhana.

Pelayanan Kesehatan Primer itu berkaitan erat dengan millenium development goals (MDG). Sejak tahun 2000 telah dikumandangkan Millenium Development Goals (MDG) yang merupakan tujuan yang harus dicapai pada tahun 2015 (Dit. Jen. Binkesmas, 2010) yang meliputi: 1) Mangatasi kemiskinan dan kelaparan yang ekstrim; 2) Pemerataan pendidikan dasar; 3) Mendukung adanya persamaan jender dan pemberdayaan perempuan; 4) Menurunkan angka kematian anak; 5) Meningkatkan kesehatan ibu; 6) Memerangi HIV/AIDS, malaria dan penyakit lainnya; 7) Menjamin kelestarian lingkungan hidup; dan 8) Mengembangkan kemitraan global untuk pembangunan. Bila $8 M D G$ ini tercapai, maka tercapainya awal kesejahteraan masyarakat, yang selanjutnya tentu perlu dikembangkan lagi.

Yang menjadi pertanyaan adalah 1) Bagaimana kaitan antara pelayanan kesehatan primer dengan MDG? 2) Bagaimana mengukur bahwa pelayanan kesehatan primer itu efektif, efisien dan bermutu? 3) Sampai dimana pemerintah mempunyai commitment membiayai pelayanan kesehatan primer? 4) Dalam rangka desentralisasi pelayanan kesehatan, sampai dimana penguasa daerah menyokong pelayanan kesehatan primer? 5) Sampai dimana lembaga pendidikan kesehatan masyarakat menghasilkan lulusan yang kompeten dalam manajemen pelayanan kesehatan primer? Apakah DPR telah menggunakan peranannya untuk memberdayakan pelayanan kesehatan primer?

\section{Kaitan Pelayanan Kesehatan Primer dengan MDG}

Bila diperhatikan 8 tujuan dari MDG tersebut di atas, maka tujuan MDG nomor 4, 5, 6 dan 7 menyangkut bidang kesehatan. Pelayanan kesehatan primer dalam MDG adalah gizi, pelayanan kesehatan ibu dan anak, pemberantasan penyakit menular khususnya TB, malaria, HIV/AIDS, air bersih dan obat esential. Namun kegiatan pelayanan kesehatan primer jangan hanya terarah kepada $M D G$ yang merupakan program internasional, jangan kita lengah terhadap penyakit-penyakit menular lainnya, penyakit tidak menular dan program-program kesehatan lainnya (Gani, 2011). Dengan demikian pencapaian MDG hanya sebagian dari tujuan yang seharusnya dicapai oleh program-program dalam pelayanan kesehatan primer, walaupun mungkin sebagai prioritas. Tujuan suatu program adalah untuk mengatasi situasi masalah melalui determinant atau berpengaruh terhadap situasi masalah itu. 


\section{Pengambilan Keputusan Berdasarkan Bukti}

Untuk mengukur pelayanan kesehatan yang efektif, efisien dan bermutu diperlukan pengambilan keputusan berdasar bukti dalam manajemen pelayanan tersebut. Ini merupakan suatu ide, hasil kreativitas dari para ahli berbagai ilmu antara lain Epidemiologi. Aplikasi dari pengambilan keputusan berdasar bukti kepada manajemen pelayanan/program kesehatan merupakan suatu inovasi dalam pelayanan kesehatan. Inovasi adalah aplikasi dari ide atau gagasan, yang dihasilkan oleh kreativitas yang merupakan suatu proses mental dan proses berpikir. Suatu inovasi menghasilkan jasa-jasa atau cara kerja yang lebih efisien (Setiawan, 1985).

Epidemiologi adalah ilmu yang bertujuan untuk 1) Mendiagnosis masalah kesehatan masyarakat, 2) Mengidentifikasi riwayat alamiah dan etiologi penyakit, dan 3) memberikan informasi yang dapat digunakan untuk manajemen pelayanan/program kesehatan (Lowe and Kostrzewski, 1973). Untuk mencapai 3 tujuan tersebut ada 2 Strategi Epidemiologi yaitu Surveilens Epidemiologi dan Penelitian Epidemiologi. Baik surveilens ataupun penelitian epidemiologi adalah kegiatan-kegiatan pengumpulan, pengolahan dan analisa data untuk menghasilkan informasi, dan selanjutnya mengahasilkan informasi menjadi bukti. Surveilens merupakan kegiatan rutin, sedangkan penelitian dilakukan bila tidak ada atau jarang informasi dari hasil Surveilens (Lapau, 2009).

Pengambilan keputusan berdasarkan bukti merupakan suatu pendekatan ilmiah khususnya epidemiologi yang diterapkan dalam manajemen pelayanan kesehatan sebagai suatu inovasi (Gray, 2001). Dalam hal ini dilakukan pendekatan sistem dalam pelayanan/program kesehatan sebagai berikut:

Input $\longrightarrow$ Proses $\longrightarrow$ Output $\longrightarrow$ Efek $\longrightarrow$ Dampak.

Input adalah sumber daya (tenaga manusia, fasilitas/logistik dan uang untuk pembiayaan) yang diperlukan supaya Proses yaitu kegiatan sistem berjalan sehingga secara langsung dapat dihasilkan Output yang segera dapat diukur. Bila ada masalah dalam Input dan/atau hambatan dalam Proses, maka Output tidak tercapai. Efek adalah perilaku masyarakat yang dapat menerima atau menolak pelayanan/program kesehatan, dan Dampak menggambarkan status kesehatan masyarakat yang diukur dengan angka kematian, angka penyakit dan/atau angka kecacatan. Bila masyarakat menolak sistem pelayanan/program, maka target Output tidak mungkin tercapai. Bila masyarakat menerimanya, maka Output dapat tercapai dan Dampak mungkin membaik.

Baik surveilens atau penelitian epidemiologi menghasilkan informasi. Bila ingin informasi dijadikan bukti, diperlukan 4 kegiatan yaitu relevansi, koherensi, konteks populasi dan geografi, dan siklus manajemen (Koot, 2009). Relevansi menjawab pertanyaan apakah indikator-indikator dalam Output, Proses, Input, Efek dan Dampak berhubungan satu sama lain. Koherensi menjawab pertanyaan hubungan tersebut selalu terjadi menurut waktu dan tempat. Konteks Populasi dan Geografis menjawab pertanyaan apakah informasi yang dihasilkan berguna untuk kelompok penduduk dan geografi tertentu. Siklus Manajemen menjawab pertanyaan apakah informasi yang dihasilkan berguna untuk melakukan perencanaan, pemantauan dan penilaian. Dengan menghasilkan informasi dan bukti ini akan dapat direncanakan dan dilaksanakan pelayanan kesehatan yang efektif, efesien dan bermutu.

Tujuan pelayanan atau program adalah untuk memperbaiki Dampak nya yaitu meningkatkan status kesehatan, sedangkan objektif program adalah mengusahakan supaya target Output dan Efek tercapai. Apakah pelayanan atau progam kesehatan efektif diukur dengan pencapaian Dampak, sedangkan efisien diukur dengan pencapaian target Output. Pelayanan yang bermutu diukur dengan sampai dimana standard operation procedure dari program atau sistem yang bersangkutan dilaksanakan untuk mencapai objektif.

\section{Pembiayaan Kesehatan}

Salah satu data Input di tingkat nasional pada 3 propinsi di Indonesia menunjukkan bahwa pembiayaan program upaya kesehatan masyarakat melalui pelayanan kesehatan primer berkisar antara 2,9\% $12 \%$, sedangkan biaya untuk upaya kesehatan perorangan $32,1 \%-66,6 \%$, lalu biaya pembangunan kapasitas penunjang $28,8 \%$ - 55,7\% (Gani, 2011). Jelas terlihat pembiayaan terhadap pelayanan kesehatan primer dalam arti preventif dan promotif jauh lebih kurang dari pada pelayanan kuratif yang banyak dilakukan di rumah sakit.

Pengalaman di Demark yang menangani salmonellosis dengan usaha penelitian kearah preventif jauh lebih murah dari pada pengalaman di Amerika Serikat yang menangani salmonellosis dengan hanya cara kuratif (Gani, 2011). Informasi seperti ini seharusnya menjadi pelajaran bagi kita di Indonesia, bahwa pelayanan kesehatan primer dalam arti preventif dan promotif harus lebih diprioritaskan dari pada pelayanan kuratif lewat rumah sakit.

\section{Desentralisasi Pelayanan Kesehatan}

Pengambilan Keputusan Berdasar Bukti
(PKBB) dalam manajemen pelayanan/program kesehatan tidak mudah diukur secara nasional atas dasar Data dan Informasi dari kabupaten dan propinsi. Karena itu melalui kebijakan desentralisasi pelayanan kesehatan, PKBB perlu dilakukan pada tingkat Dinas Kesehatan Kabupaten/Kota, Puskesmas dan Rumah 
Sakit. PKBB pada tingkat kabupaten bertujuan untuk 1) mengintensifkan pelaksanaan program-program kesehatan; 2) meningkatkan manajemen kesehatan; dan 3) melakukan kemitraan untuk keberhasilan butir 1) dan butir 2). Dalam rangka butir 1) diperlukan subdisiplin surveilens epidemiologi dan penelitian operasional, sedangkan dalam rangka butir 2) diperlukan subdisiplin manajemen strategi dan manajemen mutu/audit (Lapau, 2011).

Untuk mencapai 3 tujuan tersebut di atas, maka ditingkat dinas kesehatan kabupaten/kota perlu dibentuk Tim Epidemiologi Manajemen Kabupaten (TEMK) yang berfungsi sebagai berikut: 1) Memberikan keterampilan kepada staf dinas kesehatan kabupaten, puskesmas dan rumah sakit dalam rangka merencanakan dan melaksanakan surveilens epidemiologi dan pelaksanaan penelitian operasional; 2) Mengkoordinir kegiatan interpretasi informasi menjadi bukti yang dapat digunakan oleh Kepala Dinkes Kabupaten/ Kota untuk pengambilan keputusan dalam rangka menyusun perencanaan strategis dan operasional yang diadvokasikan ke BAPPEDA, DPRD dan lintas sektor; 3) membantu kepala dinas kesehatan kabupaten untuk melakukan pemantauan dan penilaian program-program kesehatan di tingkat puskesmas dibentuk pula TEMPus yaituTim Epidemiologi Manajemen Puskesmas (Lapau, 2011).

TEMK dan TEMPus berfungsi untuk melakukan interpretasi informasi menjadi bukti dalam rangka pengambilan keputusan oleh Kepala Dinas Kesehatan Kabupaten dan Kepala Puskesmas untuk perencanaan, dan untuk penilaian pelayanan/program kesehatan sehingga dihasilkan pelayanan yang efektif, efisien dan bermutu. Sampai saat ini boleh dikatakan hampir seluruh dinas kesehatan kabupaten/kota dan puskesmas belum mempunyai TEMK dan TEMPUs yang berfungsi seperti tersebut diatas.

Untuk mengisi posisi dalam TEMK diperlukan tenaga dengan kualifikasi Magister Manajemen Masyarakat Peminatan Epidemiologi Manajemen, dan untuk TEMPus diperlukan Sarjana Kesehatan Masyarakat Peminatan Epidemiologi, disamping tenaga kesehatan masyarakat lain setingkat magister yang ahli dalam promosi kesehatan, kesehatan lingkungan, kesehatan reproduksi dan lain lain.

Dalam rangka desentralisasi kesehatan itu, pelaksanaan TEMK dan TEMPus tersebut tidak berjalan sebagaimana mestinya, bahkan ada kepala daerah sering mengangkat kepala dinas kesehatan kabupaten yang tidak mempunyai latar belakang pendidikan dan keahlian kesehatan.

\section{Pendidikan Untuk Menjadi Sarjana Kesehatan Masyarakat}

Pada saat ini di Indonesia sudah berdiri sekitar 150 sampai 160 Program Studi Sarjana Kesehatan
Masyarakat yang belum mempunyai peminatan Epidemiologi Manajemen dan kurang dari 10 Program Studi Magister Kesehatan Masyarakat yang hanya 2 dengan peminatan Epidemiologi Manajemen. Walaupun sudah terlalu banyak Program Studi Kesehatan Masyarakat bediri dalam 15 tahun terakhir ini, penyakit menular tidak cenderung menurun bahkan ada yang menaik seperti HIV/AIDS, DBD dan lainlain; lalu penyakit tidak menular semakin meningkat, kesehatan lingkungan semakin merosot karena perilaku masyarakat dan kebijakan yang tidak mendukung.

\section{Peranan Dewan Perwakilan Rakyat (DPR) RI}

Dalam rangka mengurangi masalah penyakit menular dan tidak menular, maka diperlukan perbaikan kesehatan lingkungan dan perbaikan gizi, kesehatan reproduksi, dan promosi kesehatan. Untuk ini diperlukan inisiasi pemberdayaan pelayanan kesehatan primer dan mensukseskan pencapaian MDG, untuk mana diperlukan kemampuan akademis dan teknis kesehatan. Untuk keberhasilannya diperlukan kebijakan politis untuk mengatasi masalah tersebut diatas. Dalam hal ini DPR RI (Dewan Perwakilan Rakyat Republik Indonesia) yang berfungsi untuk melahirkan undang-undang dan melaksanakan pegawasan pelaksanaan kebijakan termasuk keuangan negara, supaya berinisiatif sedemikian rupa dalam rangka mengatasi masalah tersebut di atas.

\section{KESIMPULAN}

1. Masalah kesehatan baik penyakit menular ataupun penyakit tidak menular yang seharusnya dapat ditanggulangi dengan pelayanan kesehatan primer belum menunjukkan kecenderungan menurun.

2. Kebijakan pemerintah dalam merencanakan dan melaksanakan pelayanan kesehatan primer seakan-akan tergantung pada dorongan internasional saja (MDG), belum menggunakan epidemiologi dalam rangka pengambilan keputusan yang diintegrasikan dengan ilmu yang terkait dengan manajemen dan komunikasi/advokasi untuk mengatasi masalah kesehatan melalui pelayanan kesehatan primer.

3. Perhatian dan komitmen pemerintah terhadap pelayanan kesehatan primer belum optimal. Ini terlihat pada sedikitnya alokasi pembiayaan oleh pemerintah untuk pelayanan preventif dan promotif melalui pelayanan kesehatan primer dibandingkan dengan pelayanan kuratif melalui rumah sakit.

4. Dengan adanya kebijaksanaan desentralisasi pelayanan kesehatan, pemerintah daerah mempunyai kekuasaan segala-galanya termasuk mengangkat pejabat kesehatan yang tidak mempunyai keahlian kesehatan, yang tidak 
mengerti pelayanan kesehatan preventif dan promotof sehingga pelayanan kesehatan primer terabaikan.

5. Walaupun sudah banyak berdiri fakultas dan sekolah tinggi yang berkaitan dengan kesehatan masyarakat, kemampuan lulusannya belum berorientasi kepada pengambilan keputusan berdasar bukti, sehingga penentuan kebijaksanaan dan manajemen pelayanan kesehatan tidak dapat mengatasi penyakit-penyakit dan masalah kesehatan lainnya yang seharusnya dapat diatasi dengan pelayanan kesehatan primer.

\section{SARAN}

1. Supaya dibuat rencana strategis pelayanan kesehatan primer termasuk pelayanan kesehatan yang termasuk dalam MDG sebagai prioritas mulai tingkat pusat, propinsi dan kabupaten/kota, untuk mana diperlukan tenaga kesehatan yang dapat memanfaatkan epidemiologi dan ilmu yang berkaitan dengan manajemen dan advokasi serta ilmu-ilmu substantif yang relevan, sehingga dapat dihasilkan pengambil keputusan berdasar bukti, yang selanjutnya dapat mengarahkan advokasi dan manajemen pelayanan kesehatan primer yang efektif, efisien dan bermutu.

2. Pemerintah eksekutif dan legislatif perlu memberikan perhatian dan komitmen terhadap perkembangan ilmu kesehatan masyarakat supaya berguna dalam pelayanan kesehatan primer dalam bentuk pembuatan undang-undang atau peraturanperaturan yang memberikan peluang kepada pelayanan kesehatan preventif dan promotif lebih diprioritaskan dari pada pelayanan kesehatan kuratif.

3. Pemerintah eksekutif dan legislatif meninjau kembali undang-undang atau peraturan-peraturan yang sudah ada yang menyangkut kekuasaan pemerintah daerah yang kalau perlu melaksanakan koreksi sehingga jabatan kesehatan dapat diisi oleh sarjana yang mempunyai keahlian kesehatan yang relevan sehingga mampu dalam melaksanakan manajemen pelayanan kesehatan bermutu, efektif dan efisien.

4. Dilakukan evaluasi terhadap kurikulum lembagalembaga pendidikan yang melaksanakan pembelajaran kesehatan masyarakat yang bertujuan mendapatkan informasi dalam rangka menyusun kurikulum berbasis kompetensi sehingga lulusan mempunyai kemampuan teknis yang relevan dan dapat bekerja sama dalam tim untuk meningkatkan pelayanan kesehatan primer atas dasar pengambilan keputusan berdasar bukti.

5. Diharapkan DPR RI berinisiatif sesuai dengan peranannya untuk memberdayakan pelayanan kesehatan primer untuk mencapai tujuannya termask MDG.

\section{DAFTAR PUSTAKA}

Bachtiar, Adang. Isyu Terkini Kesehatan Masyarakat, disajikan pada Seminar Reformasi pelayanan Kesehatan, yang diadakan STIKES Hang Tuah Pekanbaru tanggal 9 April 2011

Departemen Kesehatan RI. Sistem Kesehatan Nasional, Jakarta: Depkes RI, 2004

Dit. Jen. Binkesmas. Bantuan Operasional Kesehatan(BOK) dan Penerapannya, disajikan pada TOT Studi Operasional BOK di Cikarang tanggal 27 Juli 2010

Gani, Ascobat. Reformasi Pembiayaan Kesehatan, makalah yang disajikan pada Seminar Reformasi Pelayanan Kesehatan yang diadakan STIKes Hang Tuah Pekanbaru tanggal 9 April 2011

Koot,Yaap.Evidence Based HealthCare, from information to evidence. A lecture given in Tropical Royal Institute, January - February 2001

Lapau, Buchari. Prinsip dan Metode Epidemiologi, Jakarta: Badan Penerbit FKUI, 2009

Lapau, Buchari. Strategi Epidemiopogi dalam Pelayanan Kesehatan, mkalah yang disaikan dam PIT Nasional II Epidemiologi di Bandung tgl 22-23 April tahun 2011

Lowe, CR and Kostrzewski. Epidemiology, a guide to teaching method, London: International Epidemiology Association, 1973

Setiawan, Boenyamin. Peranan Kreativitas dan Inovasi dalam Penelitian, Metode Penelitian Bidang Kedokteran, cetidakan kedua, editor: Aryatmo, Cokronegoro dkk, Jakarta: FKUI, 1985 